\title{
Development of international cultural relations of the Republic of Karakalpakstan
}

\author{
I.B.Jollibekova ${ }^{1}$ \\ ${ }^{1}$ PhD researcher, Karakalpak State University, Nukus, Republic of Uzbekistan \\ Email:indira.gandi@bk.ru
}

\begin{abstract}
In this article examined at development of internationalcultural connections of Republic of Karakalpakstan. Value to the revival of really national culture, spirituality, establishing aconnection with world civilization. The republic of Karakalpakstan is rich in plenty of monuments of history, archaeology and culture.

Keywords: Central Asia, Nukus, Karakalpakstan, city, international cultural relations, spirituality, archaeology, work, music, theatre, collaboration, history, tourism.

\section{INTRODUCTION}

Independence of the Republic of Uzbekistan has become a new era for the revival of national culture and our traditional programs and crafts. Establishment of the Republic of Uzbekistan's entry into the world arena. The development of national culture is of great importance for the development of all aspects of human life. The revival of spirituality and values is the main conceptual-methodological principle of the model of historical development, the unity of the universal and national spiritual basis, the cultural heritage, the revival of historical programs, the revival and development of interethnic relations, and the particular account of education and enlightenment[1, P.13].

The theater, music and creative associations and museums of Uzbekistan and the sovereign Karakalpakstan have started to visit several foreign countries to showcase their art. There were regular shows in various areas of art. In the early 1990 year, the Karakalpakstan Ministry of Culture consisted of only three theaters, two state concert organizations, three museums, and an association of national music ensembles. The Historical and Cultural Preservation Inspection included 15 children's music schools, 5 vocational schools, 208 clubs, 496 libraries, 6 cultural and leisure parks, 243 cinemas and movie theaters, and 3 libraries for 3 republican departments[2].
\end{abstract}

\section{MATERIALS AND METHODS}

Due to the relatively quick implementation of the laws, cooperation of the Republic of Uzbekistan in the international arena was established. Creative musical and theatrical groups of Uzbekistan and Karakalpakstan began to visit foreign countries, widely demonstrating their skills. There was a regular exchange of exhibitions in the various areas of art. The days of culture of different countries of the world in Uzbekistan and the days of culture, literature and art of the peoples of Karakalpakstan in the international arena enjoyed success.

In the field of tourism there has been a steady increase in the popularity of the eastern direction. Many travel agencies have noted a steady increase in the number of people willing to visit Karakalpakstan. The states of Central Asia are connected in the chain of the Great Silk Road global tourist product, which includes at least 20 countries from Japan to Europe. And in this chain, Uzbekistan occupies an important place - the country of azure domes.

Karakalpakstan has a significant fund of natural objects that could be used for tourism. These are the various landscapes of the Ustyurt plateau, the Kyzylkum desert, the valleys and the Amudarya delta.

The Baday-Tugai reserve, located in the Beruni district of the Republic of Karakalpakstan, can be used as a tourist site. Despite the small area, the animal and plant world of the reserve is rich and diverse. 
The Republic of Karakalpakstan is rich in a large number of historical, archeological and cultural monuments. According to the Institute of History of Archeology and Ethnography of the Karakalpak branch of the Academy of Sciences of the Republic of Uzbekistan, there are about 280 archaeological sites here. Chronologically, they are located from the Stone Age to the late Middle Ages (XIV century). Among the most famous archaeological monuments can be identified such as Kazakly Yatkan-Kala - the oldest capital of Khorezmshahs, Ayazkala, which is important in the "Golden Ring of Ancient Khorezm", Koy-krylgan-Kala - ancient mausoleum and temple-observatory, Toprakkala - Late Antique residence of Khorezmshahs, as well as numerous ancient and medieval cities and settlements - Guldursun, Nazlumhansulu and Shylpik[3].

The head of the tourist group from Japan, Yoheo Saban, having visited to Karakalpakstan, enthusiastically noted: "We in Japan read a lot about the Great Silk Road, its main cities - Samarkand, Bukhara, Khiva. We were pleasantly shocked by these ancient cities. But what we saw in the museums of Karakalpakstan and its historical monuments is so extraordinary! " For many years V.N. Yagodin, the director of the Institute of History, Archeology and Ethnography of the Karakalpak branch of the Academy of Sciences of the Republic of Uzbekistan, member of the New York Academy of Sciences, Doctor of History, dedicated his life to the idea of reviving international tourism in Karakalpakstan. V.N. Yagodin said: "The historical monuments of Karakalpakstan are truly unique. The Institute of History, Archeology and Ethnography of the Karakalpak Branch of the Academy of Sciences of the Republic of Uzbekistan, together with the Institute of Restoration of the city of Tashkent, is engaged in several projects to promote them in the "Golden Ring of Ancient Khorezm" cycle. Many historical sites, ancient monuments are remarkably preserved, although they appeared many thousands of years before the advent of Islam[4. P. 3.].

In the II-IV centuries AD Toprakkala was the residence of the Khorezm rulers. This site was internationally recognized due to the discovery here of the excavations, the remarkable palace structures of the Hall of Kings, the Hall of Black Warriors, the Hall of Dancing Masks, the Hall of Victory, monuments of ancient art: frescoes, clay sculptures, objects applied art.

The unique archaeological architectural object of the republic is the ancient and medieval complex Mizdahkan, located 3 kilometers from the city of Khodjeyli. Mizdahkan is the third largest city of medieval Khorezm and the center of feudal castles. Among the necropolises of different ages, one of the masterpieces of Oriental architecture stands out - the semi-underground Nazlumkhan-Sulu mausoleum, the Caliph Erezhep madrasah, the Shamun Nabi mausoleum, Jumart kassab. The rich remnants of material culture are fabrics and beads depicting birds, Coral beads, cowra shells from the Indian Ocean, fragments of Chinese celadon tableware, coins, and other things speak of Mizdahkan's trade links on the Silk Road.

A kind of sensation, in our days, a well-organized caravan service network on the Great Silk Road found on the Ustyurt plateau became a phenomenon of archeology. Caravanserai, wells and other structures preserved in the vast expanses of sand and gypsum desert. Pride and admiration are caused by wonderful historical monuments - the Daukesken mausoleum, the caravanserai of Beleuli, the fortress of Korgansha, the catchment structures that were ancient methods of irrigating land using atmospheric moisture, which indicates the high abilities of the peoples who once inhabited Ustyurt.

The route passing through the territory of Karakalpakstan has already become an integral part of transcontinental tourist routes along the Great Silk Road [2. P.199]. Over the past 2-3 years, several foreign groups have traveled on cars and motorcycles along this route. The potential available in the country for the development of international tourism, which is almost unused now, should be used in connection with its obvious environmental benefits. Archaeological sites could also be effectively used for international tourism. Together with the media, scholars, historians and museum workers in Karakalpakstan, a tourism development project was developed.

In the south-west of the capital of Karakalpakstan, a modern car camp was built. Autotourists from Kazakhstan, Russia, Turkmenistan, the Baltic States visit it daily[6].

The international tourism industry in Karakalpakstan was developed during the period of independence. A significant share in its turnover belongs to the tourist company "Ayazkalatur". It started its activities in 1998, and since 2000, the summer tourist camping "Ayazkala" began to operate with it. Near the campsite is the Ayazkala site of ancient settlement, which is of great importance in the Golden 
Ring of ancient Khorezm, nearby there is the Ayazkul lake, which is $20 \mathrm{~km}$ long. Around the expanse, the steppe, a very convenient place for excursions on foot through the settlement, for camel riding, recreation, fishing, swimming and boating on the lake. On average, Ayazkalu is visited by more than 1,000 tourists a year [5. P. 20.].

Particular attention is paid to improving the condition of summer camping. For this purpose, a project was developed, and UNESCO provided great assistance in its implementation. In 2005, on the basis of a grant from UNESCO, the company received solar panels, a filter for water purification. A UNESCO project is being implemented to conserve and build adobe structures in Central Asia. The goal is to preserve in the territory of Karakalpakstan mud buildings in the climatic conditions of the Aral Sea region.

In October 2007, in the Nukus, Bustan and Beruni, an international symposium "Aral Sea at the Crossroads of Cultures" and the second field seminar "Archeology of the ancient Tashkyrman Oasis", dedicated to the 100th anniversary of the outstanding researcher of antiquities of highlands Amudarya $\mathrm{S}$ .P Tolstova. Participants included: M. Mambetullaev (Nukus), Nikolas Boroffka (Germany), S.B. Bolelov (Russia), M.M. Rozhanskaya (Russia), I.A. Arzhantseva (Russia), Yu.F. Buryakov (Tashkent), R.A. V. Head-dong (Great Britain), M.-Sh. Kdyrniyazov (Nukus), E.A. Armarchuk (Russia), E.D. Zilivetskaya (Russia), A.I. Torgoev (Russia). The main report of the field seminar "The Archeology of the Ancient Tashkyrman Oasis" was the report of the leaders of the Karakalpak-Australian archaeological expedition of Dr. A.V. G. Betts and Doctor of Historical Sciences V.N Yagodina.

The Takshyrman oasis is one of the original centers of human habitation on the lands of the ancient irrigation of the southern delta of Akchadarya. It was based on the mainline channel, which arose in the epoch of the existence of the archaic culture of Ancient Khorezm (VI - V cc. BC), and developed in the Kangyu era (IV c. BC - I century AD) and Kushan (II - IV centuries AD) cultures. Today it is located on the territory of Ellikkala and Beruni districts. Research work here began in 1995. Excavations are carried out by the joint Karakalpak-Australian archaeological expedition, which was the result of cooperation with the University of Sydney [7].

Many thousands of years ago, the territory of modern Karakalpakstan was the cradle of one of the greatest civilizations of the ancient world. The people of Karakalpakstan have their own culture, traditions and customs.

Independent Uzbekistan attaches paramount importance to the revival of a truly national culture, spirituality, and the establishment of a connection with world civilization. For the protection of cultural monuments in the 1990th of the twentieth century, the basic documents were adopted: the Cabinet of Ministers of the Republic of Uzbekistan adopted a resolution of August 29, 1998. "On the export and import of cultural property." The law was enacted by the resolution of the Oliy Majlis of the Republic of Uzbekistan dated August 29, 1997. Its purpose was to regulate relations connected with the preservation of the cultural heritage of the people of Uzbekistan, to protect cultural property from illegal export and import, to establish a single order for export of cultural property from the Republic of Uzbekistan and their imports to the Republic of Uzbekistan, as well as promoting the development of international cultural cooperation.

\section{CONCLUSION}

The reason for the result, we can say that in recent years there have been a number of changes and transformations in the sphere of culture. Transition to market relations in the national cultural revival of Karakalpakstan has identified a number of important factors. Particular attention was paid to the issues of spiritual development of society, the comprehensively advanced human being, enrichment of spiritual culture. A number of important measures have been implemented throughout the Republic of Uzbekistan and laid the foundation for future development. Transition to market-based social and economic and ethical changes is not only a large-scale and multidimensional process, but also a major component of cultural change.

\section{REFERENCES}

1. Tabak, G. A. (2014). Rol' kul'turnykh i istoricheskikh traditsiy vo vneshney politike Respubliki Uzbekistan. (P.13). Tashkent. 
2. Material center of the Republic of Archive Karakalpakstan. 86 fond, 87-opis, 8-delo, Nukus, (P.132.)

3. Decree "On the storage of cultural and historical sites" dated December 22, 2001 Tashkent, (P.4.)

4. Karakalpak-Australian archaeological expedition // News of Karakalpakstan, (2006). - July 26. №60. Nukus. (P.4.)

5. Turaeva, M. A. (2006). "Ayazkala Tour" - a visiting card of Karakalpakstan // News of Karakalpakstan, - №76. Nukus, (P.20.)

6. Ryabikina, N. (2002). The Golden Tourism Project // Vesti Karakalpakstan, Nukus, - №71. September 3rd.

7. Aral Sea region at the crossroads of culture // Vesti Karakalpakstan. (2007). Nukus. №80. - 8 October. 